\title{
PENGARUH PENGETAHUAN LINGKUNGAN DAN SIKAP KONSUMEN TERHADAP NIAT BELI PRODUK RAMAH LINGKUNGAN (Studi Pada Konsumen Air Mineral ADES Di Kota Klaten)
}

\author{
Kussudyarsana \\ Nur Yuliana Devi \\ Universitas Muhammadiyah Surakarta \\ kus165@ums.ac.id
}

\begin{abstract}
The aim to be achieved by doing this research is to determine the effect of environmental knowledge variables and consumer attitudes in influencing the purchase intention of environmentally friendly products, as well as to determine whether consumer attitudes variables can mediate the influence of environmental knowledge on the purchase intention of environmentally friendly products. The results of this study are expected to be used as a consideration for the company in evaluating the level of service to customers, regarding whether the company can meet customer demand by preserving the surrounding environment. This research is a quantitative causal research that allows to know the relationship that is influential between two or more variables by using two hypothesis tests, simple regression analysis and multiple linear regression analysis. The population in this study is Ades mineral water consumers who live in the City of Klaten, while the study sample was 125 respondents with a non probability sampling purposive sampling method as a sampling method. Based on the results of the study that environmental knowledge has a positive effect on consumer attitudes with a value of 5,748 >t-table 1,984. While environmental knowledge has no positive effect on purchase intention with a value of 1,026 < t-table 1,985. In this study also shows that consumer scept has a positive effect on purchase intention with a value of 10,651 > t-table 1,985. Consumer attitudes are also variables that mediate the influence of environmental knowledge on purchase intentions, the results of this study indicate that consumer attitudes mediate between independent and dependent variables with a calculated t-value of 5,045 > ttable 1,985. In this study the mediating variable is a Full Mediation model because a to $\mathrm{Z}$ has a significant effect, $\mathrm{b}$ to $\mathrm{Y}$ has a significant effect, and $\mathrm{X}$ to $\mathrm{Y}$ has no significant influence.
\end{abstract}

Keywords: Environmental Knowledge; Consumer Attitudes; Purchase Intention; Environmentally Friendly Products.

\begin{tabular}{l}
\hline PENDAHULUAN \\
Permasalahan lingkungan dan \\
kesehatan yang secara langsung dan tidak \\
langsung diakibatkan oleh aktivitas \\
manusia telah menjadi masalah yang sangat \\
umum disemua kalangan. Isu ekses
\end{tabular}

pemasaran terhadap lingkungan mendapatkan perhatian serius dari pakar pemasaran, termasuk dalam hal ini Kotler (2009) yang menyatakan bahwa isu pelestarian lingkungan menjadi isu global terbesar sejak tahun 1900-an dengan berakhirnya persaingan biologi antar negara yang menghasilkan ilmuan dengan 
penemuan-penemuan terbaik pada tahun 1800-an. Masalah lingkungan yang sampai saat ini semakin memprihatinkan, masalah sampah plastik diberbagai belahan dunia termasuk di Indonesia menjadi salah satu permasalahan yang sulit untuk dipecahkan.

Melihat banyaknya masalahmasalah yang mengancam kelestarian lingkungan di Indonesia. Hal ini menuntut masyarakat dan perusahaan untuk meningkatkan kepeduliannya dalam melindungi lingkungan sekitar dengan memunculkan suatu gerakan konsumen hijau. Gerakan konsumen hijau (green consumerism) merupakan suatu bentuk aksi kepedulian dunia terhadap lingkungan (Handayani, 2012). Perusahaan-perusahaan industri juga harus bertanggung jawab atas dampak negatif yang dihasilkan oleh limbah industrinya, sehingga munculah environmentalism corporate yang merupakan bentuk kepedulian terhadap lingkungan yang dihadapi oleh perusahaan dan upaya untuk mengintegrasikan permasalahan lingkungan hidup dalam rencana strategis perusahaan.

Bentuk kepedulian perusahaan terhadap lingkungan hidup juga ditunjukkan dengan melakukan praktik pemasaran hijau (green marketing). Manfaat pemasaran hijau bagi perusahaan ialah memperoleh citra yang positif dari tanggung jawab memproduksi sebuah produk yang ramah lingkungan, sedangkan manfaat pemasaran hijau bagi konsumen ialah mendapatkan produk yang berkualitas bagi kesehatan maupun bagi lingkungannya (Utami, 2014).

Munculnya kesadaran masyarakat akan pentingnya kelestarian lingkungan hidup sehingga menyebabkan tinginya tingkat permintaan konsumen akan produkproduk ramah lingkungan telah mendorong produsen untuk merubah orientasi usaha mereka, dengan mempertimbangkan aspek ekologi selain aspek ekonomi. Green marketing dilakukan pada berbagai aktivitas pemasaran termasuk modifikasi produk, perubahan dalam proses, pergantian packaging, bahkan perubahan pada promosi. Green marketing dilakukan perusahaan untuk memenuhi kebutuhan dan keinginan konsumen akan produk ramah lingkungan sekaligus sebagai bentuk tanggung jawab perusahaan pada lingkungan hidup.

Perusahaan minuman ringan merupakan salah satu pemasok sampah plastik terbanyak, karena sebagian besar produk minuman dikemas dalam botol plastik yang tidak dapat didaur ulang. Namun demikian, sebagian dari mereka merespon secara baik ekses aktivitas mereka terhadap lingkungan. Perusahaan air mineral merupakan salah satu perusahaan industri yang dengan cepat mengeksplorasi dan meneliti cara baru, mengembangkan ide baru, dan merencanakan strategi baru untuk memposisikan produk ramah lingkungan mereka dipikiran konsumen dan untuk tetap kompetitif di pasar, sehingga dapat mencapai bisnis yang berkelanjutan (Suki, 2016).

Paparan dalam promosi tentang nutrisi, olahraga, merokok dan konsumi alkohol dapat dilakukan untuk mengubah cara orang berfikir tentang gaya hidup sehat dan bagaimana mereka berusaha untuk hidup sehat. Harus ada kesadaran tentang pentingnya program pendidikan yang diarahkan kepada masyarakat luas terutama bagi siswa, menjelaskan pentingnya gaya hidup sehat dan nilai-nilai lingkungan sebagai faktor penentu perilaku ekologi konsumen disetiap keputusan pembelian produk ramah lingkungan (Suki, 2013).

Kemungkinan bahwa tingkat pengetahuan lingkungan yang lebih tinggi dapat menghasilkan perilaku ekologis konsumen yang lebih baik (Suki, 2013). Aspek ekologis merupakan salah satu 
faktor utama dalam pelestarian alam selain aspek sosial dan produksi, ekologis sangat erat hubungannya dengan lingkungan dan pencemaran (Ginting, 2016). Pengetahuan tentang lingkungan merupakan informasi yang disimpan dalam ingatan seseorang mengenai lingkungan yang ada di sekitarnya. Pengetahuan lingkungan adalah pengetahuan dasar seseorang tentang sesuatu yang dapat dilakukan untuk membantu melindungi lingkungan (Lee, 2011). Terdapat hubungan yang signifikan antara pengetahuan lingkungan dan perilaku konsumen hijau (Mostafa, 2009). Jika seseorang memiliki pengetahuan tentang sebab dan dampak pada lingkungan, tingkat kesadaran mereka akan meningkat dan perpotensi mempromosikan sikap yang menguntungkan terhadap produk hijau. Kepedulian lingkungan mengacu pada tingkat keterlibatan emosional individu dalam isu-isu lingkungan yang merupakan respon afektif individu terhadap perlindungan lingkungan (Lee, 2008). Tujuan penelitian ini untuk mengetahui pengaruh pengetahuan lingkungan dan sikap konsumen terhadap niat beli produk ramah lingkungan.

\section{REVIEW LITERATUR}

\section{Landasan Teori}

Pengetahuan adalah informasi atau maklumat yang diketahui atau disadari oleh seseorang. Pengetahuan merupakan sesuatu yang didapatkan dari hasil daya tahu yang nantinya dapat berbentuk sebuah informasi. Proses dari daya tahu tersebut seperti melihat, mendengar, merasakan, dan berfikir yang menjadi dasar manusia untuk bertindak dan bersikap. Pengetahuan adalah jumlah informasi yang ada di dalam memori seseorang yang mempengaruhi cara dimana konsumen menafsirkan dan menilai pilihan yang tersedia. Secara konseptual, pengetahuan konsumen dapat dibagi menjadi dua komponen, yaitu pengetahuan obyektif dan pengetahuan subjektif. Pengetahuan obyektif mengacu pada isi dan organisasi pengetahuan (pengetahuan faktual) yang disimpan dalam memori seseorang (Junline, 2016). Hal ini mengacu pada apa yang seorang individu benar-benar tahu tentang jenis produk atau masalahobjek. Sedangkan pengetahuan subjektif mengacu pada persepi atau penilaian individu tentang apa yang mereka tahu dan berapa banyak mereka tahu tentang produk, masalah, atau objek.

Pengetahuan konsumen adalah segala informasi yang konsumen ketahui tentang berbagai macam produk dan jasa, pengetahuan terikat dengan produk dan jasa tersebut serta informasi lain yang berkaitan dengan fungsinya sebagai konsumen. Seorang konsumen yang memiliki pengetahuan banyak akan melakukan pembelian keputusan dengan lebih efektif dan efisien (Sumarwan , 2004).

Chen (2013) berpendapat bahwa pengetahuan lingkungan adalah serangkaian pengetahuan ekologis yang dimiliki oleh individu mengenai lingkungan. Semakin baik pengetahuan lingkungan yang dimiliki oleh konsumen, maka konsumen tersebut akan semakin tahu tentang kualitas produk ramah lingkungan dan akan meningkatkan motivasi mereka untuk membeli produk ramah lingkungan. Lee (2011) mendefinisikan bahwa pengetahuan mengenai lingkungan adalah suatu pengetahuan dasar yang dimiliki oleh seseorang mengenai segala hal yang dapat dilakukan dan diusahakan untuk membantu dalam perlindungan lingkungan dengan memfasilitasi komitmen perilaku mereka untuk melakukan pembelian hijau. Pengetahuan terhadap lingkungan dapat didefinisikan sebagai sebuah pengetahuan umum tentang fakta, konsep dan hubungan antara lingkungan alam dengan ekosistem disekitarnya (Utami, 2014). 
Adil (2015) menyatakan bahwa pengetahuan lingkungan merupakan informasi yang disimpan dalam ingatan mengenai lingkungan yang ada di sekitar konsumen, pentingnya pengetahuan lingkungan pada konsumen, serta disisi lain kepedulian perusahaan untuk dapat memberikan informasi yang jelas sebagai upaya edukasi bagi konsumen. Schahn (1990) menyatakan terdapat dua jenis pengetahuan lingkungan yaitu pengetahuan abstrak (pengetahuan yang terkait dengan isu-isu lingkungan, masalah, penyebab, dan solusi) dan pengetahuan konkrit seperti pengetahuan faktual.

\section{Hipotesis}

\section{Pengaruh Positif Pengetahuan Lingkungan Terhadap Sikap Konsumen}

Pengetahuan mengenai lingkungan dapat berpengaruh terhadap sikap konsumen. Pengetahuan adalah jumlah informasi yang ada di memori seseorang yang mempengaruhi cara dimana konsumen menafsirkan dan menilai pilihan yang tersedia. Semakin tingginya tingkat pengetahuan dan perhatian lingkungan yang dimiliki seorang konsumen, maka semakin tinggi pula sikap ekologis yang dimiliki konsumen tersebut dibandingkan dengan konsumen yang tidak memiliki pengetahuan dan perhatian terhadap lingkungan yang selanjutnya mempengaruhi perilaku ekologisnya.

Penelitian yang dilakukan oleh Rini (2017) menjelaskan bahwa adanya pengaruh antara pengetahuan lingkungan terhadap sikap konsumen. Kotler (2009) berpendapat bahwa sikap adalah pandangan tentang kesukaan atau ketidaksukaan secara evaluasi, perasaan, dan kecenderungan terhadap suatu objek atau ide. Sikap merupakan predisposisi yang dipelajari untuk memberi respon favourable (suka) atau tidak favourable (tidak suka) terhadap objek tertentu (Sumarsono, 2012). Sikap konsumen adalah prediktor terbaik dari niat beli, bahkan persepsi efektivitas konsumen memiliki dampak pada sikap niat beli produk ramah lingkungan. Sikap adalah suatu ekspresi yang merefleksikan perasaan ketidaksukaan dan kesukaan seseorang terhadap suatu obyek.

Sikap merupakan kecenderungan faktor emosional yang belum menjadi tindakan. Sikap merupakan hasil belajar. Sikap merupakan nilai yang bervariasi (suka tidak suka). Sikap ditujukan terhadap suatu objek, bisa personal atau nonpersonal. Perubahan yang terjadi pada diri seseorang biasanya dipengaruhi oleh kejadian dan pengalaman yang tidak terduga sebelumnya. Melalui tindakan yang dilakukannya, orang tersebut dapat menentukan sikap yang paling tepat untuk memecahkan suatu permasalahan. Gordon Allport dalam Sutisna (2001), mendefinisikan sikap adalah mempelajari kecenderungan memberikan tanggapan pada suatu obyek atau kelompok obyek baik disenangi atau tidak disenangi secara konsisten.

Sikap adalah inti dari perasaan suka atau tidak suka seseorang terhadap suatu objek tertentu. Sikap merupakan tanggapan perasaan seseorang terhadap konsumen yang bisa berupa perasaan suka atau tidak suka terhadap objek tertentu. Sikap disebut juga konsep yang paling khusus dan sangat dibutuhkan dalam psikologi sosial kontemporer. Sikap juga merupakan salah satu konsep yang paling penting digunakan pemasar untuk memahami konsumen. Sikap pada lingkungan merupakan utama dalam usaha meningkatkan kualitas lingkungan, 
konsumen yang mempunyai sikap positif terhadap lingkungan akan cenderung mengembangkan sikap positif terhadap produk dan kegiatan yang konsisten dengan nilai tersebut (Adil, 2015). Sikap menempatkan orang dalam kerangka pemikiran mengenai menyukai atau tidak menyukai sesuatu, menyukai sesuatu atau menjahuinya. Sikap konsumen konatif merupakan kencenderungan berperilaku tertentu sesuai dengan sikap yang dimiliki oleh seseorang. Hal ini berisi tendensi atau kecenderungan untuk bertindak atau bereaksi terhadap sesuatu dengan cara-cara tertentu. Berdasarkan uraian di atas, maka dapat dibentuk hipotesis sebagai berikut:

H1: Pengetahuan Lingkungan Berpengaruh Positif Terhadap Sikap Konsumen.

\section{Pengaruh Positif Pengetahuan Lingkungan Terhadap Niat Beli Konsumen}

Niat beli diperoleh dari suatu proses belajar dan proses pemikiran yang membentuk suatu presepsi. Niat beli dapat menciptakan suatu motivasi yang akan terekam dalam memorinya dan menjadi suatu keinginan yang sangat kuat dan pada akhirnya ketika seorang konsumen harus memenuhi kebutuhannya akan mengaktualisasikan apa yang ada didalam memorinya tersebut. Menurut Saraswaty (2015) niat beli terhadap suatu produk timbul karena kepercayaan yang telah dimiliki konsumen mengenai produk tersebut disertai dengan adanya kemampuan membeli produk tersebut. Menurut Junaedi (2006), niat beli adalah sikap konsumen terhadap produk yang terdiri dari kepercayaan konsumen terhadap merek dan evaluasi merek, sehingga dari dua tahap tersebut muncul niat untuk membeli. Semakin rendah tingkat kepercayaan konsumen terhadap suatu produk dapat menyebabkan semakin menurunnya niat beli konsumen.

Aman (2012) menjelaskan bahwa terdapat hubungan antara pengetahuan lingkungan terhadap niat beli produk ramah lingkungan. Hasil penelitiannya menunjukkan bahwa semakin besar pengetahuan lingkungan yang dimiliki konsumen terhadap adanya isu-isu lingkungan, maka semakin besar pula niat beli produk ramah lingkungan.

Menurut Mowen (2007) niat beli adalah penentu dari pembeli untuk melakukan pembelian suatu produk atau jasa. Niat itu sendiri merupakan gabungan dari kepercayaan dengan sikap konsumen terhadap produk atau jasa. Niat beli merupakan komponen kognitif dan afektif dari komponen sikap, dimana niat pembelian merupakan tindakan konsumen sebelum melakukan keputusan pembelian.

Kotler (2009) juga berpendapat bahwa niat beli konsumen adalah sebuah perilaku konsumen dimana konsumen mempunyai keinginan dalam membeli atau memilih suatu produk, berdasarkan pengalaman dalam memilih, menggunakan dan mengkonsumsi atau bahkan menginginkan suatu produk. Berdasarkan uraian di atas, maka dapat dibentuk hipotesis sebagai berikut:

H2: Pengetahuan Lingkungan Berpengaruh Positif Terhadap Niat Beli Produk Ramah Lingkungan.

\section{Pengaruh Positif Sikap Konsumen Terhadap Niat Beli Produk Ramah Lingkungan}

Sikap merupakan prediktor penting bagi perilaku, minat berperilaku dan merupakan faktor penjelas dari berbagai macam perilaku individu. Perubahan yang terjadi pada diri seseorang biasanya dipengaruhi oleh kejadian dan pengalaman yang tidak terduga 
sebelumnya. Melalui tindakan yang dilakukannya, orang tersebut dapat menentukan sikap yang paling tepat untuk memecahkan suatu permasalahan. Penelitian yang dilakukan oleh Suki (2016) memperlihat bahwa sikap konsumen secara positif mempengaruhi niat pembelian. Aman (2012) juga membuktikan dalam penelitiannya bahwa ada pengaruh antara sikap konsumen terhadap niat beli produk ramah lingkungan.

Theory of reasoned action mengemukakan bahwa orang mempertimbangkan konsekuensi dari perilaku alternatif sebelum terlibat di dalamnya, dan bahwa mereka memilih untuk melakukan perilaku yang mereka asosiasikan dengan hasil yang diinginkan. Dalam model theory of reasoned action perilaku ditentukan oleh niat seseorang untuk melakukan perilaku tersebut. Fishbein (1975) menyarankan bahwa niat perilaku (behaviour intention) berasal dari dua faktor: (1) sikap terhadap perilaku, dan (2) norma subyektif (atau tekanan sosial yang dirasakan terkait dengan perilaku).

Menurut Barr (2007) niat beli adalah keinginan untuk memiliki produk, niat beli dapat timbul apabila seorang konsumen sudah terpengaruh terhadap mutu dan kualitas dari suatu produk. Niat bisa datang dari dalam diri konsumen itu sendiri, konsumen dapat memutuskan kapan akan menggunakan dan membeli produk tersebut. Selain itu niat bisa datang dari rangsangan luar yaitu datang dari pengaruh orang-orang sekitar yang menggunakan suatu produk tertentu. Berdasarkan uraian di atas, maka dapat dibentuk hipotesis sebagai berikut:

H3: Sikap Konsumen Berpengaruh Positif Terhadap Niat Beli Produk Ramah Lingkungan.

\section{Peran Pemediasi Sikap Konsumen Pada Pengaruh Positif Pengetahuan Lingkungan Terhadap Niat Beli Produk Ramah Lingkungan}

Pengetahuan lingkungan yang tinggi dapat meningkatkan sikap konsumen dan secara bersama-sama dapat meningkatkan niat beli produk ramah lingkungan.

H4: Peran Pemediasi Sikap Konsumen Pada Pengaruh Positif Pengetahuan Lingkungan Terhadap Niat Beli Produk Ramah Lingkungan.

\section{Model Penelitian}

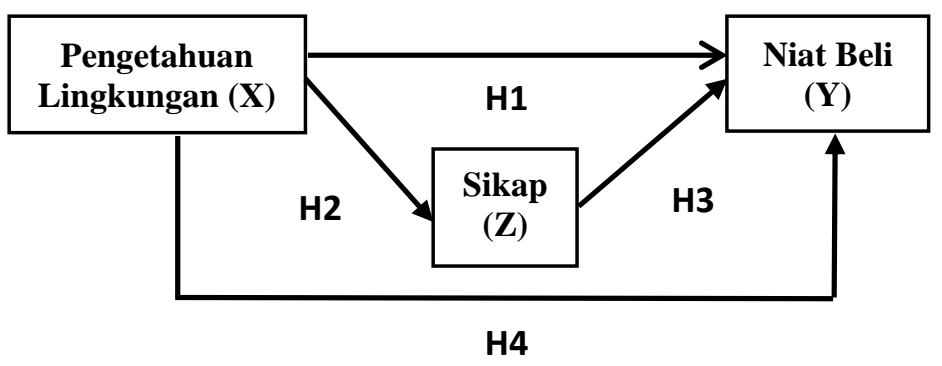

Gambar 1. Model Penelitian

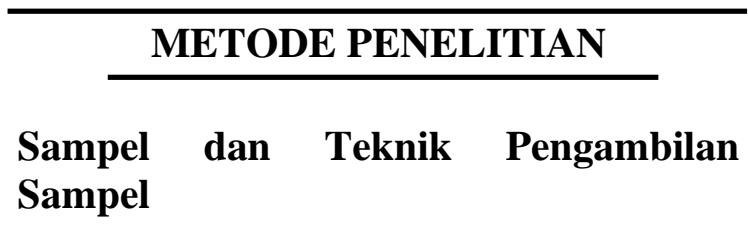

Penelitian ini merupakan penelitian kuantitatif yang bersifat kausal merupakan jenis penelitian yang menjelaskan hubungan (sebab-akibat) yang bersifat mempengaruhi antar dua variabel atau lebih (Setiawan, 2014). Data primer dalam penelitian ini diperoleh langsung melalui pengisian kuesioner oleh konsumen yang pernah melakukan pembelian produk air mineral kemasan bermerek ADES di Kota Klaten.

Sampel yang digunakan dalam penelitian ini disesuaikan dengan metode, jumlah sampel yang dibutuhkan paling sedikit 25 kali jumlah variabel independen. Sehingga minimal yang dibutuhkan pada penelitian ini adalah 50 sampel, tetapi 
peneliti mengambil 125 sampel pada penelitian ini. Pengambilan sampel dilakukan dengan metode purposive sampling, yaitu metode pengambilan sampel yang dilakukan berdasarkan kriteria yang telah ditentukan oleh peneliti. Kriteria pengambilan sampel purposive sampling dalam penelitian ini sebagai berikut: (a) Responden pernah membeli produk minuman kemasan bermerek ADES, (b) Responden merupakan seseorang yang tinggal atau menetap di Kota Klaten.

\section{Uji Validitas}

Sugiyono (2010) menjelaskan bahwa uji validitas adalah uji statistik yang digunakan untuk menentukan seberapa valid suatu item pertanyaan mengukur variabel yang diteliti. Item-item terebut mampu memberikan dukungan dalam mengungkap apa yang ingin diungkap atau dinyatakan valid. Kuesioner dikatakan valid jika pertanyaan pada kuesioner mampu mengungkapkan sesuatu yang akan diukur oleh kuesioner terssebut. Kuisioner dapat dikatakan valid apabila nilai faktor loading lebih besar dari 0,5 .

\section{Uji Reliabilitas}

Sugiyono (2010) menjelaskan bahwa instrumen yang reliabel adalah yang bila digunakan beberapa kali untuk mengukur objek yang sama akan mendatangkan data yang sama. Dengan menggunakan instrumen yang valid dan reliabel dalam pengumpulan data, maka diharapkan hasil penelitian akan menjadi valid dan reliabel. Intrumen dapat dikatakan reliabel apabila nilai Cronbach Alpha lebih dari 0,6.

\section{Uji Asumsi Klasik}

\section{Uji Normalitas}

Uji normalitas dilakukan dengan metode Kolmogorov-Smirnov dengan kriteria jika nilai signifikasi KolmogorovSmirnov lebih besar $\alpha=0,05$ maka dengan demikian bisa dikatakan asumsi normalitas terpenuhi (Sidanti, 2015).

\section{Uji Heteroskedastisitas}

Untuk menguji heteroskedastisitas menggunakan uji Breusch Pagan Godfrey dengan melihat nilai signifikansi sebesar 0,05 atau 5\% (Ghozali, 2012).

\section{Uji Multikolinieritas}

Uji multikolinearitas bertujuan untuk mengetahui hubungan masingmasing variabel independen (Sam'ani, 2008). Multikolinearitas tidak terjadi apabila nilai Tolerance berada di atas 0,1 dan nilai VIF di bawah 10 (Rimardhani, 2016).

\section{Analisis Regresi Linier Berganda}

Analisis regresi berganda digunakan untuk mengetahui seberapa besar pengaruh antara pengetahuan lingkungan (X) dan sikap konsumen (Z) terhadap niat beli produk ramah lingkungan (Y).

\section{Persamaan regresi linear berganda model I}

Teknik regresi digunakan untuk melakukan prediksi seberapa jauh nilai variabel independen $X$ mempengaruhi nilai variabel $Z$. Berikut adalah persamaan regresi berganda model I:

$$
\mathbf{Z}=\mathbf{a}+\mathbf{b} \mathbf{1} \mathbf{x} \mathbf{1}
$$

\section{Persamaan linear berganda model II}

Teknik regresi digunakan untuk mengetahui seberapa jauh nilai variabel $\mathrm{X}$ dan variabel $Z$ terhadap variabel Y. Berikut adalah persamaan regresi berganda model II:

$$
\mathbf{Y}=\mathbf{a}+\mathbf{b X}+\mathbf{b Z}
$$

\section{Uji Koefisien Determinasi}

Uji ini digunakan untuk mengukur seberapa jauh kemampuan model regresi dalam menjelaskan variasi variabel dependen (Ghozali, 2012). Nilai koefisien determinasi besarnya antara 0 (nol) dan 1 (satu). Apabila nilai R2 mendekati 0, maka kemampuan variabel independen dalam menjelaskan variabel dependen masih 
terbatas. Sebaliknya, jika nilai R2 mendekati 1, maka kemampuan variabel independen dalam menjelaskan variabel dependen cukup baik.

\section{Analisis Jalur (Sobel Test)}

Analisis jalur merupakan perluasan dari analisis regresi linear berganda. Analisis regresi dilakukan sebanyak dua kali. Analisis regresi yang pertama untuk mengetahui kekuatan hubungan dari variabel bebas (independent) terhadap variabel mediasi (intervening). Analisis regresi yang kedua untuk mengetahui kekuatan hubungan dari variabel bebas (indenpendent) terhadap variabel terikat (dependent).

Pengujian hipotesis mediasi atau intervening dilakukan dengan prosedur yang dikembangkan oleh Sobel (1982) dan dikenal dengan uji Sobel (Sobel test) (Ghozali, 2012). Uji Sobel dilakukan dengan cara menguji kekuatan pengaruh tidak langsung $\mathrm{X}$ ke $\mathrm{Y}$ melalui $\mathrm{Z}$.

\section{HASIL PENELITIAN DAN PEMBAHASAN}

\section{Hasil Penelitian}

\section{Hasil Uji Validitas}

Tabel 1. Hasil Uji Validitas

\begin{tabular}{|c|c|c|c|}
\hline \multicolumn{4}{|c|}{ Pattern Matrix ${ }^{a}$} \\
\hline & \multicolumn{3}{|c|}{ Component } \\
\hline & 1 & 2 & 3 \\
\hline $\mathrm{X} 1$ & & .797 & \\
\hline $\mathrm{X} 2$ & & .761 & \\
\hline $\mathrm{X} 3$ & & .595 & \\
\hline $\mathrm{X} 4$ & & .662 & \\
\hline X5 & & .657 & \\
\hline $\mathrm{Z1}$ & .835 & & \\
\hline $\mathrm{Z2}$ & .830 & & \\
\hline $\mathrm{Z3}$ & .864 & & \\
\hline $\mathrm{Z4}$ & .875 & & \\
\hline Y1 & & & .805 \\
\hline Y2 & & & .835 \\
\hline Y3 & & & .787 \\
\hline Y4 & & & .806 \\
\hline Y5 & & & .840 \\
\hline
\end{tabular}

Sumber: Data Primer Diolah (2019)
Berdasarkan tabel 1 di atas, menunjukkan bahwa item pertanyaan sudah dinyatakan valid, karena setiap item pertanyaan yang menjadi indikator masing-masing variabel mempunyai nilai korelasi item pertanyaan dengan konstruk lebih dari 0,5.

\section{Hasil Uji Reliabilitas}

Tabel 2. Hasil Uji Reliabilitas

\begin{tabular}{lcl}
\hline Variabel & Cronbach Alpha & Keterangan \\
\hline Pengetahuan Lingkungan & 0,782 & Reliable \\
Sikap Konsumen & 0,918 & Reliable \\
Niat beli & 0,859 & Reliable \\
\hline
\end{tabular}

Sumber: Data Primer Diolah (2019)

Dari tabel 2 di atas, diketahui bahwa hasil pengujian reliabilitas variabel pengetahuan lingkungan, sikap konsumen, dan niat beli konsumen diperoleh nilai Cronbach Alpha lebih besar dari kriteria yang ditentukan adalah 0,6 yang mana menjelaskan bahwa semua variabel dinyatakan reliabel.

\section{Hasil Uji Normalitas}

Tabel 3. Hasil Uji Normalitas

\begin{tabular}{|c|c|c|c|c|}
\hline & & $X$ & Z & $\mathrm{Y}$ \\
\hline \multirow[t]{2}{*}{$\mathrm{N}$} & & 100 & 100 & 100 \\
\hline & Mean & 20.5000 & 13.9300 & 16.7200 \\
\hline Normal Parameters ${ }^{\mathrm{a}, \mathrm{b}}$ & $\begin{array}{l}\text { Std. } \\
\text { Deviation }\end{array}$ & 3.27987 & 3.21064 & 3.26314 \\
\hline \multirow{3}{*}{$\begin{array}{l}\text { Most Extreme } \\
\text { Differences }\end{array}$} & Absolute & .164 & .154 & .119 \\
\hline & Positive & .103 & .109 & .107 \\
\hline & Negative & -.164 & -.154 & -.119 \\
\hline \multicolumn{2}{|c|}{ Kolmogorov-Smirnov Z } & 1.637 & 1.539 & 1.191 \\
\hline \multicolumn{2}{|l|}{ Asymp. Sig. (2-tailed) } & .009 & .018 & .117 \\
\hline
\end{tabular}

Berdasarkan tabel 3 dapat disimpulkan bahwa nilai residual yang terdapat dalam variabel dependen terdistribusi dengan normal, karena angka signifikansi uji KS sebesar 1,191 $>$ 0,05 dengan Asymp. Sig (2-tailed) $0,177>0,05$. Sedangkan untuk variabel independen tidak berdistribusi normal, 
karena nilai Asymp. Sig (2-tailed) < 0,05 .

\section{Hasil Uji Multikolinieritas}

Tabel 4. Hasil Uji Multikolinieritas

\begin{tabular}{|c|c|c|c|c|c|c|c|}
\hline \multicolumn{8}{|c|}{ Coefficients $^{\mathrm{a}}$} \\
\hline \multirow[t]{2}{*}{ Model } & \multicolumn{2}{|c|}{$\begin{array}{l}\text { Unstandardized } \\
\text { Coefficients }\end{array}$} & \multirow{2}{*}{$\frac{\begin{array}{c}\text { Standardized } \\
\text { Coefficients }\end{array}}{\text { Beta }}$} & \multirow[t]{2}{*}{$t$} & \multirow[t]{2}{*}{ Sig. } & \multicolumn{2}{|c|}{$\begin{array}{c}\text { Collinearity } \\
\text { Statistics }\end{array}$} \\
\hline & $B$ & $\begin{array}{l}\text { Std. } \\
\text { Error }\end{array}$ & & & & Tolerance & VIF \\
\hline (Constant) & 4.516 & 1.299 & & 3.476 & .001 & & \\
\hline X & .073 & 071 & .073 & 1.026 & .307 & .748 & 1.337 \\
\hline Z & .769 & .072 & .757 & 10.651 & .000 & .748 & 1.337 \\
\hline
\end{tabular}

Sumber: Data Primer Diolah (2019)

Berdasarkan tabel 4 di atas, dapat disimpulkan bahwa tidak terdapat korelasi yang tinggi antar variabel independen, karena nilai VIF tidak ada yang mendekati angka 10.

\section{Hasil Uji Heteroskedastisitas}

\section{Tabel 5. Hasil Uji Heteroskedastisitas}

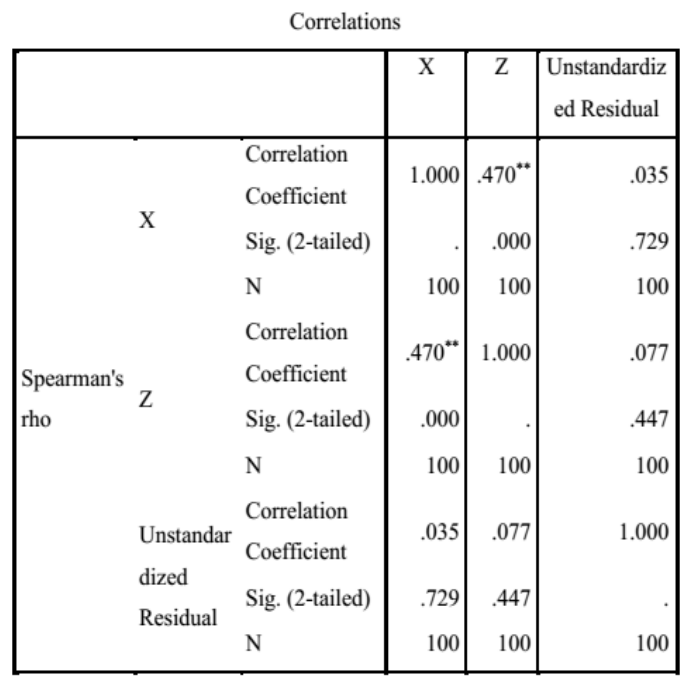

Sumber: Data Primer Diolah (2019)

Berdasarkan tabel 5 di atas, menunjukkan bahwa nilai signifikan variabel pengetahuan lingkungan, dan sikap konsumen $>0,05$, maka dapat disimpulkan bahwa variabel pengetahuan lingkungan dan sikap konsumen tidak terjadi heterokedastisitas.

\section{Hasil Analisis Regresi Linier Berganda}

Tabel 6. Hasil Uji Regresi Model 1

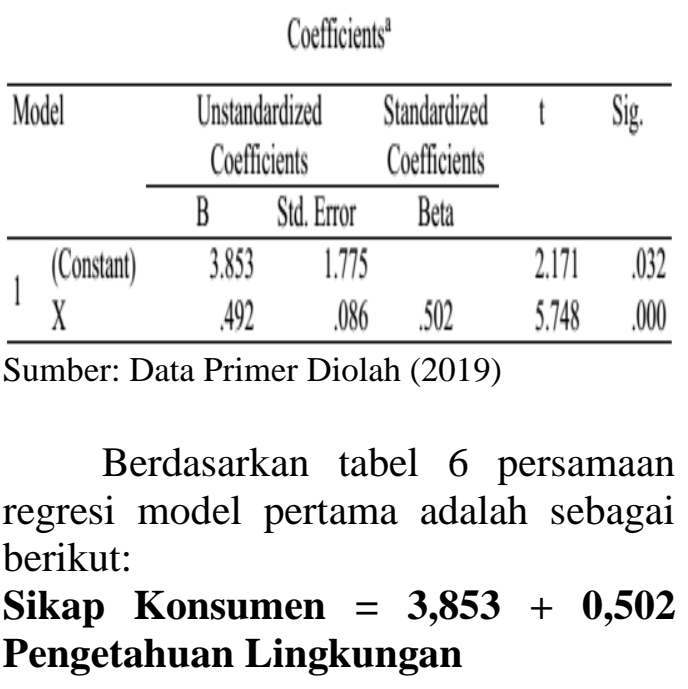

Tabel 7. Hasil Uji Regresi Model 2

Coefficients $^{\mathrm{a}}$

\begin{tabular}{|c|c|c|c|c|c|c|}
\hline \multirow[t]{2}{*}{$\overline{M o d}$} & & \multicolumn{2}{|c|}{$\begin{array}{l}\text { Unstandardized } \\
\text { Coefficients }\end{array}$} & \multirow{2}{*}{$\begin{array}{l}\begin{array}{c}\text { Standardized } \\
\text { Coefficients }\end{array} \\
\text { Betta }\end{array}$} & \multirow[t]{2}{*}{$t$} & \multirow[t]{2}{*}{ Sig. } \\
\hline & & $B$ & Std. Error & & & \\
\hline \multirow{3}{*}{1} & (Constant) & 4.516 & 1.299 & & 3.476 & .001 \\
\hline & X & .073 & .071 & .073 & 1.026 & .307 \\
\hline & Z & .769 & .072 & .757 & 10.651 & .000 \\
\hline
\end{tabular}

Sumber: Data Primer Diolah (2019)

Berdasarkan tabel 7 di atas, hasil pengelolaan data untuk regresi linier dapat disusun persamaan sebagai berikut:

Niat Beli Produk Ramah Lingkungan $=4,516+0,073$ Pengetahuan Lingkungan + 0,769 Sikap Konsumen

\section{Hasil Uji Parsial (Uji T)}

Tabel 8. Hasil Uji Parsial Model 1 Coefficients $^{\mathrm{a}}$

\begin{tabular}{|c|c|c|c|c|c|}
\hline \multirow[t]{2}{*}{ Model } & \multicolumn{2}{|c|}{$\begin{array}{l}\text { Unstandardized } \\
\text { Coefficients }\end{array}$} & $\begin{array}{l}\text { Standardized } \\
\text { Coefficients }\end{array}$ & $t$ & Sig. \\
\hline & B & Std. Error & Beta & & \\
\hline (Constant) & 3.853 & 1.775 & & 2.171 & .032 \\
\hline$X$ & .492 & .086 & .502 & 5.748 & .000 \\
\hline
\end{tabular}

Sumber: Data Primer Diolah (2019) 
Berdasarkan hasil pengujian diperoleh nilai probabilitas lebih kecil dari $0,05(0,000<0,05)$, maka variabel pengetahuan lingkungan memiliki pengaruh yang signifikan terhadap sikap konsumen.

\section{Tabel 9. Hasil Uji Parsial Model 2} Coefficients $^{a}$

\begin{tabular}{|c|c|c|c|c|c|c|}
\hline \multirow[t]{2}{*}{ Mode } & & \multicolumn{2}{|c|}{$\begin{array}{c}\text { Unstandardized } \\
\text { Coefficients }\end{array}$} & \multirow{2}{*}{$\begin{array}{l}\begin{array}{c}\text { Standardized } \\
\text { Coefficients }\end{array} \\
\text { Beta }\end{array}$} & \multirow[t]{2}{*}{$t$} & \multirow[t]{2}{*}{ Sig. } \\
\hline & & B & Std. Error & & & \\
\hline \multirow{3}{*}{1} & (Constant) & 4.516 & 1.299 & & 3.476 & .001 \\
\hline & X & 073 & .071 & .073 & 1.026 & .307 \\
\hline & Z & .769 & .072 & .757 & 10.651 & .000 \\
\hline
\end{tabular}

Sumber: Data Primer Diolah (2019)

Berdasarkan tabel 9 di atas, menunjukkan bahwa variabel pengetahuan lingkungan tidak berpengaruh signifikan terhadap niat beli produk ramah lingkungan yang dibuktikan dengan nilai koefisien lebih besar dari $0,05(0,307>0,05)$. Selanjutnya, sikap konsumen memiliki pengaruh yang signifikan terhadap niat beli produk ramah lingkungan yang dibuktikan dengan nilai koefisien lebih kecil dari 0,05 $(0,000<0,05)$.

\section{Hasil Uji Koefisien Determinasi Tabel 10. Hasil Uji Keofisien Determinasi Model 1}

\begin{tabular}{|c|c|c|c|c|}
\hline \multicolumn{5}{|c|}{ Model Summary ${ }^{\mathrm{b}}$} \\
\hline Model & $\mathrm{R}$ & R Square & $\begin{array}{l}\text { Adjusted R } \\
\text { Square }\end{array}$ & $\begin{array}{l}\text { Std. Error of } \\
\text { the Estimate }\end{array}$ \\
\hline 1 & $.502^{\mathrm{a}}$ & .252 & .245 & 2.79063 \\
\hline
\end{tabular}

Sumber: Data Primer Diolah (2019)

Berdasarkan tabel 10 di atas, dapat dilihat bahwa nilai $\mathrm{R}$ Square sebesar 0,252. Artinya, $25,2 \%$ variabel sikap konsumen dapat dijelaskan oleh variabel pengetahuan lingkungan. Sedankan sisanya $74,8 \%$ dijelaskan oleh variabel lain yang tidak ada dalam penelitian.
Tabel 11. Hasil Uji Keofisien Determinasi Model 2

\begin{tabular}{lcccr}
\multicolumn{5}{c}{ Model Summary $^{\mathrm{b}}$} \\
\hline Model & R & R Square & $\begin{array}{c}\text { Adjusted R } \\
\text { Square }\end{array}$ & $\begin{array}{c}\text { Std. Error of } \\
\text { the Estimate }\end{array}$ \\
\hline 1 & & \multicolumn{4}{c}{$.796^{\mathrm{a}}$} & .634 & .626 & 1.99532 \\
\hline Sumber: Data Primer Diolah (2019)
\end{tabular}

Berdasarkan tabel 11 di atas dapat dilihat bahwa nilai $\mathrm{R}$ Square sebesar 0,634 . Artinya $63,4 \%$ variabel niat beli produk ramah lingkungan dapat dijelaskan oleh variabel pengetahuan lingkungan dan sikap konsumen. Sedangkan sisanya 36,6\% dijelaskan oleh variabel lain yang tidak ada dalam penelitian ini.

\section{Hasil Analisis Jalur}

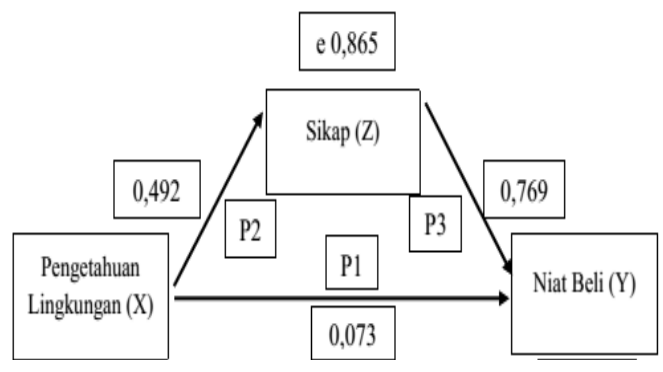

Gambar 2. Hasil Analisis Jalur

Pengujian Sobel Test:

$S p 2 p 3=\sqrt{p 3^{2} S p 2^{2}+p 2^{2} S p 3^{2}+S p 2^{2} S p 3^{2}}$

$S p 2 p 3=\sqrt{(0,769)^{2}(0,086)^{2}+(0,492)^{2}(0,072)^{2}+(0,086)^{2}(0,072)^{2}}$

$\mathrm{Sp} 2 \mathrm{p} 3=0075$

Menhitung nilai t statistik pengaruh intervening

$$
\begin{aligned}
\text { thitung } & =\frac{p 2 p 3}{\text { Sp2p3 }} \\
& =\frac{(0,492)(0,769)}{(0,075)}=5,045
\end{aligned}
$$

Berdasarkan perhitungan di atas, diperoleh nilai t-hitung sebesar 5,045 yang mana lebih besar dari t-tabel 1,985. Disimpulkan bahwa koefisien mediasi adalah signifikan, artinya terdapat pengaruh mediasi dari variabel sikap konsumen. 


\section{Pembahasan}

\section{Pengaruh Positif Pengetahuan Lingkungan Terhadap Niat Beli Produk Ramah Lingkungan}

Pengetahuan adalah jumlah informasi yang ada didalam memori seseorang yang mempengaruhi cara dimana konsumen menafsirkan dan menilai pilihan yang tersedia. Secara konseptual, pengetahuan konsumen dapat dibagi menjadi dua komponen: pengetahuan obyektif dan pengetahuan subjektif. Pengetahuan obyektif mengacu pada isi dan organisasi pengetahuan (pengetahuan faktual) yang disimpan dalam memori seseorang. Hal ini mengacu pada apa yang seorang individu benar-benar tahu tentang jenis produk, masalah, atau obyek. Sedangkan pengetahuan subyektif mengacu pada presepsi atau penilaian individu tentang apa yang mereka tahu dan berapa banyak mereka tahu tentang produk, masalah, atau objek.

Berdasarkan hasil penelitian di atas, dapat diperoleh nilai probabilitas lebih besar dari $0,05(0,307>0,05)$. Artinya pengetahuan lingkungan tidak berpengaruh positif terhadap niat beli produk air mineral ramah lingkungan Ades.

Hasil penelitian ini tidak sesuai dengan penelitian yang dilakukan oleh Ginting (2016) yang menyatakan bahwa pengetahuan lingkungan memiliki pengaruh positif dan signifikan terhadap niat beli produk hijau. Pengetahuan lingkungan tidak mempengaruhi niat beli produk ramah lingkungan karena merupakan variabel yang tidak dapat berdiri sendiri dan membutuhkan variabel yang dapat menghubungkan antara variabel pengetahuan lingkungan dengan variabel niat beli, karena semakin tinggi pengetahuan lingkungan, maka yang akan dipengaruhi adalah sikap konsumen dan hal ini akan meningkatkan motivasi konsumen.

\section{Pengaruh Positif Pengetahuan Lingkungan Terhadap Sikap Konsumen \\ Menurut Chen (2013), pengetahuan lingkungan adalah} serangkaian pengetahuan ekologis yang dimiliki individu mengenai lingkungan. Semakin baik pengetahuan lingkungan yang dimiliki oleh konsumen, maka konsumen tersebut akan semakin memahami tentang kualitas produk ramah lingkungan serta akan meningkatkan motivasi mereka untuk membeli produk ramah lingkungan sehingga niat beli konsumen akan meningkat. Berdasarkan hasil penelitian statistik di atas, dapat diperoleh bahwa nilai probabilitas lebih kecil dari 0,05 $(0,000<0,05)$. Artinya pengetahuan lingkungan berpengaruh positif terhadap sikap konsumen produk air mineral ramah lingkungan Ades. Hasil penelitian ini merupakan jawaban dari setiap responden terhadap item pertanyaan variabel pengetahuan lingkungan. Semakin tinggi pengetahuan lingkungan seseorang, maka akan mempengaruhi sikap konsumen.

Hasil penelitian ini sesuai dengan penelitian yang dilakukan oleh Sumarsono (2012), yang menyatakan bahwa pengetahuan lingkungan berpengaruh positif terhadap niat beli dan sikap konsumen pada lingkungan. Seperti penelitian oleh Aman (2012) yang menunjukkan bahwa semakin besar pengetahuan lingkungan yang dimiliki konsumen terhadap adanya isuisu lingkungan akan semakin besar pula niat beli produk dan sikap konsumen produk ramah lingkungan. Meningkatnya pengetahuan lingkungan dapat meningkatkan pula sikap 
konsumen dengan cara berupaya menambah wawasan tengtang pengetahuan lingkungan dan pada akhirnya konsumen akan berupaya untuk memperbaiki sikap dan menjaga kelestarian lingkungan hidup dengan membuat sebuah gerakan konsumen hijau yaitu konsumen lebih memilih produk-produk dimana bahan baku, proses produksi, kemasan, dan produk sisa pakainya ramah lingkungan.

\section{Pengaruh Positif Sikap Konsumen Terhadap Niat Beli Produk Ramah Lingkungan}

Menurut Kotler (2009) sikap adalah pandangan tentang kesukaan atau ketidaksukaan secara evaluasi, perasaan, dan kecenderungan terhadap suatu objek atau ide. Fishbein (1975) mendefinisikan sikap sebagai kecenderungan belajar untuk merespon secara konsisten baik atau cara yang tidak menguntungkan sehubungan dengan objek yang diberikan. Berdasarkan hasil penelitian statistik diatas, dapat diperoleh nilai probabilitas lebih kecil dari $0,05(0,000$ $<0,05)$. Artinya sikap konsumen berpengaruh positif terhadap niat beli produk air mineral ramah lingkungan Ades. Hasil penelitian ini sesuai dengan penelitian yang dilakukan oleh Adil (2015) yang menyatakan bahwa sikap terhadap lingkungan berpengaruh positif pada niat beli produk ramah lingkungan.

Sikap konsumen selalu menarik bagi pemasar karena dapat membantu untuk memahami bagaimana konsumen berfikir, merasakan, memilih produk atau merek dan mengukur sikap pelanggan telah menjadi fenomena penting. Sikap merupakan predisposisi yang dipelajari untuk memberikan respon suka maupun tidak suka terhadap suatu objek tertentu sehingga semakin konsumen menyukai suatu produk maka niat beli konsumen akan meningkat terutama bagi konsumen hijau dimana mereka telah terfokus pada produkproduk yang memiliki bahan-bahan, kemasan dan proses produksi yang ramah lingkungan maka niat beli terhadap air mineral dengan kemasan yang ramah lingkungan akan meningkat.

\section{Peran Pemediasi Sikap Konsumen} Pada Pengaruh Positif Pengetahuan Lingkungan Terhadap Niat Beli Produk Ramah Lingkungan

Berdasarkan perhitungan uji mediasi di atas, maka diperoleh nilai thitung sebesar 5,045 lebih besar dari ttabel 1,985 $(5,045>1,985)$, maka dapat disimpulkan bahwa koefisien mediasi adalah positif, artinya sikap konsumen memediasi pengaruh pengatahuan lingkungan terhadap niat beli produk ramah lingkungan. Hasil hipotesis tentang peran sikap dalam memediasi pengaruh pengetahuan lingkungan terhadap niat beli produk ramah lingkungan menunjukkan hasil yang positif signifikan. Itu berarti bahwa pengetahuan lingkungan yang tinggi menyebabkan sikap konsumen yang positif pada lingkungan, oleh sebab itu dari sikap akan menimbulkan pengaruh niat konsumen untuk membeli produk ramah lingkungan tersebut. Hasil penelitian ini sesuai dengan penelitian yang dilakukan oleh Putri (2015) yang menyatakan bahwa sikap konsumen signifikan memediasi secara parsial pengaruh pengetahuan lingkungan terhadap niat membeli produk hijau atau produk ramah lingkungan.

\section{KESIMPULAN DAN SARAN}

\section{Kesimpulan}

Berdasarkan hasil analisis data yang dilakukan dapat diambil kesimpulan sebagai berikut: 
1. Pengetahuan lingkungan berpengaruh signifikan terhadap sikap konsumen. Hal ini dibuktikan dengan nilai probabilitas lebih kecil dari $0,05(0,000<0,05)$. Hipotesis pertama yang mengatakan pengetahuan lingkungan berpengaruh signifikan terhadap sikap konsumen diterima.

2. Pengetahuan lingkungan tidak berpengaruh signifikan terhadap niat beli produk ramah lingkungan. Hal ini dibuktikan dengan nilai probabilitas lebih besar dari 0,05 $(0,307>0,05)$. Hipotesis kedua yang mengatakan pengetahuan lingkungan berpengaruh signifikan terhadap niat beli produk ramah lingkungan ditolak.

3. Sikap konsumen berpengaruh signifikan terhadap niat beli konsumen. Hal ini dibuktikan dengan nilai probabilitas lebih kecil dari $0,05(0,000<0,05)$. Hipotesis ketiga yang mengatakan sikap konsumen berpengaruh signifikan terhadap niat beli produk ramah lingkungan diterima.

4. Sikap memediasi pengaruh positif pengetahuan lingkungan terhadap niat beli produk ramah lingkungan. Hal ini disebabkan karena t-hitung variabel sikap konsumen sebesar $5,045>$ t-tabel 1,985. Hipotesis keempat yang mengatakan peran pemediasi sikap konsumen pada pengaruh signifikan pengetahuan lingkungan terhadap niat beli produk ramah lingkungan diterima.

\section{Saran}

Saran bagi penelitian selanjutnya yaitu pertama, sebaiknya peneliti melakukan penelitian dengan memilih organisasi atau perusahaan yang berbeda dari penelitian sebelumnya. Kedua, penelitian selanjutnya dapat mempertimbangkan berbagai faktor lainnya yang dapat mempengaruhi niat beli konsumen seperti: persepsi nilai konsumen, karakteristik demografi, gaya hidup, persepsi manfaat, budaya, kepercayaan pada produk, dan lain-lain yang dapat dimasukkan sebagai variabel mediasi atau moderasi.

\section{DAFTAR PUSTAKA}

Adil, A. (2015). Pengaruh Pengetahuan Tentang Lingkungan, Sikap Pada Lingkungan, dan Norma Subjektif Terhadap NiatPembelian green Product. Jurnal Ekonomi dan Kewirausahaan, 122-128.

Aman, A. L., Harun, A., \& Hussein, Z. (2012). The Influence of Environmental Knowledge and Concern on Green Purchase Intention the Role of Attitude as a Mediating Variable. British Journal of Arts and Social Sciences, 145-167.

Barr, M. S. (2007). Factors Influencing Environmental Attitudes and Behaviors . Environment and Behavior, 435-473.

Chen, L. (2013). A Study of Green Purchase Intention Comparing with Collectivistic (chinese) and Individualistic (American) Consumers in Shanghai. Information Management and Business Review, 342-346.

Fishbein, M., \& Ajzen, I. (1975). Belief, attitude, intention and behaviour: An introduction to theory and research. Reading, MA: Addison-Wesley.

Ghozali, I. (2012). Aplikasi Analisis Multivariate dengan Program IBM SPSS 20 edisi 6. Semarang: Badan Penerbit Universitas Diponegoro.

Ginting, R. K., \& Ekawati, W. N. (2016). Penggaruh Pengetahuan Lingkungan 
Terhadap Niat Membeli Produk Hijau Pada Merek "Attack" Dengan Kepedulian Lingkungan Sebagai Variabel Mediasi. E-Jurnal Manajemen Unud, 2223-2249.

Handayani, N. T. (2012). Pengaruh Atribut Produk Terhadap Loyalitas Pelanggan Green Product Sepeda Motor Honda Injection. Management Analysis Journal, 1-6.

Junaedi, M. S. (2006). Pengembangan Model Perilaku Konsumen Berwawasan Lingkungan di Indonesia: Studi Perbandingan Kota Metropolitan dan Non Metropolitan. Jurnal Ekonomi dan Bisnis Indonesia, 399-419.

Junline. (2016). Analisis Pengetahuan Lingkungan dan Perilaku Ramah Lingkungan Berdasarkan Gender dan Tingkat Pendidikan Di Kota Pekanbaru.

Kotler, P., \& Keller, K. L. (2009). Manajemen Pemasaran (13th ed). Jakarta: Erlangga.

Lee, K. (2008). Opportunities For Green Marketing: Young Consumers. Marketing Intellegence \& Planning, 586-592.

Lee, K. (2011). The Green Purchase Behaviour of Hong Kong Young Consumers: The Role of Peer Influence, Local Environmental Involvment, and Concrete Environmental Knowledge. Journal of Internasional Consumer Marketing, 21-44.

Mostafa, M. (2009). Shades of Green. A psychograpic segmentation of the green consumer in Kuwait Uising selforganizing maps. Expert System With Applications, 11030-11038.

Mowen, J., \& Minor, M. (2007). Perilaku Konsumen, edisi kedelapan, jilid 1. Jakarta: PT Penerbit Erlangga.

Putri, P. P., Sukaadmadja, I. G., \& Suprapti, N. S. (2015). Peran Sikap Dalam Memediasi Pengaru Pengetahuan
Tentang Lingkungan Terhadap Niat Membeli Produk Hijau Pendingin Udara Merek LG di Denpasar. E Jurnal Manajemen Universitas Udayana.

Rimardhani, H., \& Hidayat, R. R. (2016). Pengaruh Mekanisme Good Corporate Governance Terhadap Profitabilitas Perusahaan (Studi Pada Perusahaan BUMN Yang Terdaftar di BEI Tahun 2012-2014). Jurnal Administrasi Bisnis, 31(1).

Rini, A. S., Sukaatmadja, I., \& Giantari, I. A. (2017). PENGARUH PENGETAHUAN LINGKUNGAN DAN KEPEDULIAN LINGKUNGAN TERHADAP SIKAP DAN NIAT BELI PRODUK HIJAU "THE BODY SHOP” DI KOTA DENPASAR. E Jurnal Ekonomi dan Bisnis Universitas Udayana, 137-166.

Sam'ani. (2008). Pengaruh Good Corporate Governance Dan Leverage Terhadap Kinerja Keuangan Pada Perbankan yang Terdaftar di Bursa Efek Indonesia (BEI) Tahun 2004- 2007. Tesis Tidak Dipublikasikan. Magister Manjemen, Universitas Diponegoro Semarang.

Saraswaty, W., \& Suprapti, N. S. (2015). Peran Sikap Dalam Memediasi Pengaruh Kepedulian Lingkungan Terhadap Niat Beli Produk Ramah Lingkungan. E Jurnal Manajemen Unud, 2407-2427.

Setiawan, W., \& Sugiharto, S. (2014). Pengaruh Marketing Mix Terhadap Keputusan Pembelian Toyota Avanza Tipe G di Surabaya. Jurnal Manajemen pemasaran.

Schahn, J., \& Holzer, E. (1990). Studies Of Individual Environmental Concern. The Role Of Knowledge, Gender And Background Variables. Environment and Behaviour.

Sidanti, Heny. (2015). Pengaruh Lingkungan Kerja, Disiplin Kerja dan 
Motivasi Kerja Terhadap Kinerja Pegawai Negeri Sipil di Sekeretariat DPRD Kabupaten Madiun. Vol.9 No.1.

Sugiyono. (2010). Metodologi Penelitian Kuantitatif Kualitatif dan $R \& D$. Bandung: CV Alfabeta.

Suki, N. M. (2013). Young consumer ecological behaviour: The effects of environmental knowledge, healthy food, and healthy way of life with the moderation of gender and age. An International Journal, 726-737.

Suki, N. M. (2016). Green product purchase intention: impact of green brands, attitude, and knowledge. British Food Journal, 2893-2910.

Sumarsono, \& Giyanto, Y. (2012). Analisis Sikap dan Pengetahuan Konsumen Terhadap Ecolabelling serta Pengaruhnya pada Keputusan Pembelian Produk Ramah Lingkungan. Performance, $70-85$.

Sumarwan, U. (2004). Perilaku Konsumen: Teori dan Penerapannya dalam Pemasaran. Bogor: PT Ghalia Indonesia.

Sutisna. (2001). Perilaku Konsumen \& Komunikasi Pemasaran. Bandung: PT Remaja Rosdakarya.

Utami, R. D., Gunarsih, T., \& Aryanti, T. (2014). Pengaruh Pengetahuan, Kepedulian dan Sikap pada Lingkungan Terhadap Minat Pembelian Produk Hijau. Media Trend, 151-161. 